\title{
Collective and Individual Responsibility in International Law with Particular Regard to the Punishment of War Criminals
}

\author{
Hans Kelsen*
}

$\mathrm{A}^{\text {MONG all postwar problems none is more constantly discussed }}$ and no demand more rightly made than that the persons who, as members of the governments or of the armed forces, or as subjects of the Axis Powers, have committed certain offenses against international law should be brought to justice. ${ }^{1}$ What are the offenses for which retribution may be claimed, and what are the principles of justice applicable to these offenses?

I.

The offenses for which retribution may be claimed are, in the first place, violations of international law committed by having resorted to war in disregard of general or particular international law, or by

*Lecturer, Political Science, University of California; drafted Austrian Republican Constitution of 1920; Member and Permanent Reporter, Austrian Court of Constitution, 1920-1930; Professor of Law at the Universities Vienna, Cologne, Prague, at the Graduate Institute of International Studies, Geneva; Oliver Wendell Holmes Lecturer, 1940-41, at Harvard Law School.

1 The punishment of war criminals plays an important role in the Declaration signed on November 1, 1943, at the historic Three Power Conference in Moscow. Since the United States, Great Britain, and Soviet Russia made the punishment of the war criminals one of their war aims, it is fruitless to raise the question whether it is advisable, from the point of view of the future peace, to institute, after or during the war, legal procedures for the punishment of war crimes. In a discussion on the establishment of an international criminal court which took place at the Thirty-third Conference of the International Law Association beld at Stockholm in 1924, Sir Graham Bower said: "There is no nation in the world which bas not violated the laws of war, and there is no army or navy in the world which has not committed war crimes." And further: "What will be the consequences [of a punishment of war criminals]? When the soldiers and sailors have finished fighting, when they are ready to shake hands over a treaty of peace, then the lawyers are to begin a war of accusation and counter-accusation and recrimination, which will be worse than war. General Sherman said, 'War is Hell,' and he spoke the truth; but, with all due respect, I submit that if this proposal were adopted, it would make peace a liell." Sir Graham Bower terminated his speech by saying: "A bas la guerre des procès, vive la paix de l'oubli et de l'espérance." (1925) The Internationai Law Assoctation Report of tHe Thirty-thimb Conference 93, 95. 
having provoked war, that is to say, by having committed the international delict against which the war has been a just reaction. It is a fundainental principle of general international law that war is permitted only as reaction against a wrong suffered, that is to say, as a sanction, and that any war which has not this character is a violation of international law. This is the principle of bellum justum (just war.) $)^{2}$ There can be no doubt that Gerinany, by resorting to war against Poland and Soviet Russia; Italy, by resorting to war against France; and Japan, by resorting to war against China and the United States, have violated this principle. By resorting to war, the Axis Powers have in addition violated the Kellogg-Briand Pact by which war is outlawed as a means of national policy; noreover, Germany, by resorting to war against Poland and Soviet Russia has violated the non-aggression pacts concluded with the attacked States. The demand to punish the war criminals is, or should be, above all, the demand to punish the authors of the second World War, the persons inorally responsible for one of the greatest crimes in the history of mankind.

In the second place, the crimes for which retribution may be claimed are breaches of the rules of international law regulating the conduct of war, such as the Hague Convention of 1907 respecting the laws and customs of war on land, the Geneva Convention of 1929 concerning the treatment of sick and wounded and of prisoners of war, and many other rules of customary and conventional international law regarding warfare. These are "war crimes" in the narrower sense of the term. Some writers consider as war crimes also all hostilities in arms committed by individuals who are not inembers of the eneiny armed forces, espionage and war treason, and finally, all marauding acts. ${ }^{3}$

War crines in the wider sense of the term, including offenses of international law committed by resorting to or provoking war, are delicts in a strictly legal sense. They are violations of international law committed by States or by individuals; the latter inay or may not be nembers of the armed forces. War crimes in the narrower sense of the term are at the same time violations of national (municipal) law in so far as they constitute crimes according to the general criminal law of a State or according to particular norms of its crimi-

2 Most of the writers on international law do not recognize the principle of just war as a rule of positive law. In Keisen, Law and PEace in Intrernationac ReLations (1942) pp. 34 et seq., I presented the main arguments pro and contra this view.

3 Cf. 2 Oppeneretar, InTERaAtionat Law (6th ed. 1940) 450 et seq. 
nal law providing sanctions against the violations of the rules of international law concerned. War crimes (in the broader sense of the term) may be committed on the territory of the State which, or whose subject, is the delinquent, or on enemy territory occupied by the anned forces of the State which, or whose subject, is the delinquent.

The demand for retribution is sometines extended to violations of the principles of humanity, that is to say, to acts which, though not illegal from the point of view of international or national law, are breaches of the norms of morality against which neither international nor national law provides any sanction, and for which no legal responsibility is established. The problem of punishing these offenses is not within the scope of the present essay.

"Primciples of justice" to be applied in the trials of the war criminals is understood to be the law which can and should be applied to punish the criminals-international or national (municipal) law. If international law, existing general or particular international law, or international law to be created in the future by international treaty; if national law, the law of the State which has, or whose subjects have, been injured by the crime, or the law of the State which has, or whose subjects have, committed the crine. These questions are closely connected with the question as to whether an international court or national courts shall have jurisdiction over the crimes concerned; and if national courts, whether civil or military courts of the injured States or of the State whose subjects are to be punished.

II.

To answer these questions we must first of all note that the demand for punishunent of war criminals means making the individuals responsible by punishing them for acts committed by themselves or for acts committed at their command or with their authorization. It does not mean to punish a State as such, that is, a State as a body corporate. It is generally assumed that the sanctions which international law provides against States as such, namely reprisals and war, are not punishments in the sense of criminal law. The difference, however, between the specific sanctions of international law directed against States and the sanctions of criminal law directed against individuals is not clearly manifest. Punishment is forcible deprivation of life, freedom, or property for the purpose of retribution or prevention. This definition applies to the specific sanctions of international law as well. The fact that the perpetrator must have a guilty 
mind does not, as is sometimes maintained, exclude "punishment" of States. The rule of mens rea is not without exceptions. Cases of absolute liability are not completely excluded, even in modern criminal law. Moreover, according to some writers, a State is responsible for its acts only if they are committed by its organs willfully and maliciously or with culpable negligence. ${ }^{4}$ The opinion that the State as a body corporate cannot have a guilty mind because it has no psychic functions, ${ }^{5}$ is not conclusive. The State acts only through individuals; acts of State are acts performed by individuals in their capacity as organs of the State and therefore acts imputed to the State. If only acts committed "willfully and maliciously or with culpable negligence" are imputable as delicts to the State, it is quite possible to say that the State must have a "guilty mind" in order to be made responsible for a delict. If it is possible to impute physical acts performed by individuals to the State although the State has no body, it must be possible to impute psychic acts to the State, although the State has no soul. Imputation to the State is a juristic construction, not a description of natural reality. 5 .

The difference between the punishment provided by national law and the specific sanctions of international law-reprisals and warconsists in the fact that punishment-at least in modern criminal law-constitutes individual responsibility, whereas the specific sanctions of international law constitute collective responsibility. Punishment is directed against the individual who, by his own conduct, has violated the law, has committed the crime; criminal law directs its sanctions against an individual precisely determined as the individual who by his own conduct has performed the act which constitutes the crime. Thus criminal law establishes individual responsibility. The specific sanctions of international law-reprisals and war - are not directed against the individual whose conduct constitutes the violation of international law. Reprisals and war are directed

${ }^{4}$ Cf. e.g. 1 Oppenhen, International LaW (5th ed. 1935) 277.

- Cf. e.g. Fischer Wurtadis, Chapters on Current International LaW and the LEAGUE OF NATIONS (1929) 234.

5a The possibility of a criminal responsibility of the State is maintained-in opposition to the prevailing doctrine: societas delinquere non potest-by Vespasian V. Pella, "De l'influence d'une Jurisdiction criminelle internationale", (1936) 3 Revor INTERNATIONALE DE DRoIT PÉNAL, 391 et seq. His main argument, however, that the State is a real being, not a legal fiction, is not correct. The decisive question is not whether the State is a real being or a legal fiction, but the question, whether the sanctions which are to be directed against the State as such, sanctions constituting collective responsibility, can have the character of "punishment". 
against the State as such, and that means against the subjects of the State-against individuals who have not committed the delict or had the ability to prevent it. The individuals against whom reprisals and war are directed are the subjects of the State whose organ has violated international law. International law answers the question, "Against whom are the sanctions to be directed?", not, as national criminal law does, by determining a certain human being individually, but by determining a certain group of individuals-individuals who stand in a certain legal relation to the person who, by his own conduct, has performed the act constituting the delict-namely, the individuals who are the subjects of the State whose organ has committed the delict. This is collective responsibility. The statement that according to international law the State is responsible for its acts means that the subjects of the State are collectively responsible for the acts of the organs of the State; and the statement that international law imposes duties on States and not on individuals means, in the first place, that the specific sanctions of international law-reprisals and war-constitute collective, not individual, responsibility.

Since the demand to punish the war criminals aims at individual responsibility of the persons who by their own conduct have performed the crimes, it seems impossible to satisfy this demand on the basis of general international law.

\section{III.}

The establishment of collective responsibility by imternational law, however, only establishes a rule with important exceptions. There are norms, of general international law by which the person against whom a sanction is to be directed is individually determined as the person who, by his own conduct, has violated international law. These norms establish individual responsibility. Such a norm of general international law is the rule forbidding piracy. The delict, committed on the open sea, is directly determined by general international law, which authorizes the States to attack, seize, and punish the pirate. International law does not authorize the States to resort to reprisals or war against the State whose subject or vessel has committed acts of piracy. It authorizes the States to execute sanctions only against the individuals who committed acts of piracy. The norm of general international law conferring upon States the legal power to prosecute pirates is a restriction of another rule of general international law; namely, the rule establishing the freedom of the open sea. If inter- 
national law would not confer upon the States the right to attack, seize, and punish the pirate, these acts would be violations of the principle of the freedom of the open sea. Only by a norm of general international law can the norm establishing the freedom of the open sea be restricted. The fact that the specification of the punishment is left to national law, and the trial of the pirate to national courts, does not deprive the delict and the sanction of their international character. A State which in its criminal law attaches to piracy a certain punishment, and punishes a pirate through its courts executes international law, and functions as an organ of the international community, just as a State which resorts to reprisals against another State which has violated the former's right, enforces international law. Reprisals are international sanctions because their legal basis is international law, although they are executed by organs of the injured State. The same is true of the punishment of pirates by national courts; a court is an organ of the State just as are its administrative agencies or its armed force through which the State exercises reprisals. The rule of general international law forbidding piracy is a rule of international criminal law, imposing a legal duty directly upon individuals and establishing individual responsibility. Consequently, the doctrine that international law by its very nature cannot oblige individuals, and hence cannot have the character of criminal law, is not correct.

Other norms of general international law by which individuals are directly obligated and individual responsibility is established are the rules concerning breach of blockade and carriage of contraband. In these cases general international law not only determines directly the individual against whom a sanction is to be directed, but also specifies the sanction which is the confiscation of the vessel and the cargo. The national prize courts, by deciding cases of blockade and contraband, execute not only national, but also international law and hence function not only as organs of national but also of international law. Whether the sanction has in these cases the character of "punishment", or resembles more civil execution, is of no importance. It is decisive that a rule of general international law establishes imdividual responsibility-the responsibility of the owner of the vessel and the cargo, guilty of breach of blockade or carriage of contraband.

Another example of direct obligation of individuals and individual responsibility established by general international law is the rule concerning a specific act of illegitimate warfare, sometimes charac- 
terized as a "war crime". It is the rule of general international law according to which private individuals, not belonging to the armed forces of the enemy who take up arms against the armed forces of the occupant state, may be considered by the latter as criminals. International law confers upon the occupant State the right to punish those individuals for acts of illegitinate warfare, even if these acts are not crimes according to the law of their country and although the occupant State is, as a rule, obliged to apply to the inhabitants of the occupied country their own law. These acts are forbidden directly by international law. The military court, by punishing the acts, executes international law even if it applies at the same time norms of its own military law. The legal basis of the trial is international law which establishes the individual responsibility of the person committing the act of illegitimate warfare. If it must be admitted that international law gives the occupant State the right to punish inhabitants of the occupied territory for acts of illegitimate warfare, then it is inconsistent to say-as, for instance, Oppenheim does ${ }^{0^{\circ}}$ - that international law, as a law between States only, cannot prohibit private individuals from taking up arms and committing hostilities against the enemy. For, to "prohibit" legally a certain conduct means nothing else than to attach to that conduct a sanction, and international law, by giving the occupant State "the right" to punish acts of illegitimate warfare, prohibits these acts, which may not be prohibited by the national law of the perpetrators.

Some violations of international law may be committed by acts of individuals injurious to other States-acts which are not acts of State, but acts for which the State, in whose territory the acts have been committed, is responsible in so far as the State is obliged to prevent these acts, and, if prevention is not possible, to punish the delinquents and compel them to pay damages. These are cases of so-called vicarious responsibility of the State for acts that are not its own acts. By punishing them, the State executes international law, even if national law is also applied to the delinquents. If national law attaches sanctions to the acts concerned, it does so in execution of international law. Consequently, one can say that international law, at least indirectly, imposes upon the individuals the obligation to abstain from such acts injurious to other States, and that international law, mdirectly, establishes individual responsibility.

62 OpPENHETM, op. cit. supra note 3 , at 455 . 
IV.

It stands to reason that individual responsibility for war crimes can be established by particular international law, for instance by an international treaty. An example is the abortive treaty relating to the use of submarines concluded at Washington on February 6, 1922. Article 3 of this treaty states that any person in the service of any State who shall violate any rule of this treaty relative to the attack, capture, or destruction of commercial ships, whether or not he is under order of a governmental superior, ". . . shall be deemed to have violated the laws of war and shall be liable to trial and punishment as if for an act of piracy and may be brought to trial before the civil or military authorities of any Power within the jurisdiction of which he may be found." According to general international law, a person who, in the service of a State, has violated a rule of international law is not responsible. But by an international treaty, such persons can be made responsible. The treaty of Washington is problematical only in so far as it does not restrict its validity to the contracting States. As we shall see later, an individual who, in his capacity as an organ of a State, has violated international law can be made responsible for such an act of State by another State only with the consent of his home State. The attempt to overcome this difficulty by using the fiction that violation of the norms of the Treaty of Washington are to be considered as piracy, for which general international law establishes individual responsibility, is vain, since a violation of the Treaty of Washington is not piracy. ${ }^{7}$

The International Convention for the Protection of Submarine Telegraph Cables, signed at Paris on March 14, 1884, is also an example of a rule of international law directly obligating individuals and establishing individual responsibility. Article II of the Conven-

7 The delicts determined by the Washington Treaty are not piracy because piracy cannot be an act of State, whereas the delicts determined by the Washington Treaty may be, and mostly are, acts of State. Consequently, the Treaty could be valid only for the contracting parties which confer upon each other jurisdiction over the perpetrators even in case the latter have acted at their Government's command or with its authorization. Cf. infra p. 539 et seq. Roxburgh, Submarines at the Washington Conference, THE BRITISH YEARBOOR OF INTERNATIONAT LAW (1922-1923) 154, correctly says: "Piracy is essentially a crime committed without the authority of any State." The jurisdiction "over piracy cannot give rise to diplomatic complications just because piracy is a crime which cannot be committed by the authority of any State . . . but submarine offenses, unlike piracy, are very liable to be committed by the authority of a State, and consequently this universal jurisdiction, [provided by the Treaty of Washington] . . . if exercised, might well lead to serious disputes." 
tion stipulates: "The breaking or injury of a submarine cable, done willfully or through culpable negligence, and resulting in the total or partial interruption or embarrassment of telegraphic communication, shall be a punishable offense, but the punishment inflicted shall be no bar to a civil action for damages." A norm of international law directly defines a delict and attaches criminal as well as civil sanction to an act committed by an individual determined by this norm. The Convention obliges the States to specify by their national law the sanctions (pumishinent and civil execution) provided for by Article II, and obliges the State to which the vessel belongs and on board which the delict defined in Article II was committed, to execute the sanctions. The national courts, by punishing an individual for the breaking or injury of a subinarine cable or by ordering reparation of the damage caused by the delict, execute international law even if they apply their national law at the same time. The individuals concerned are obliged by international law to abstain from a delict determined by international law, even if their national law also requires the same conduct. Their criminal, as well as their civil, responsibility is directly established by international law, in addition to its establishment by national law. This interpretation is correct even if the courts are obliged by the constitution of their State to apply only statutes enacted by the legislative organ of their State, so that a so-called transformation of a norm of international into national law is necessary in order to be executed within the State. The necessity of transforming international into national law, imposed by a national constitution, cannot alter the fact that the enactunent of the statute by which the transformation is carried out and its application by the courts is an execution of international law, the fulfillment of an international obligation of the State, whose legislative and judicial organs function here as organs of international law.

V.

If the individuals who are morally responsible for this war, the persons who have, as organs of their States, disregarded general or particular international law, and have resorted to or provoked this war, if these individuals as the authors of the war shall be made legally responsible by the injured States, it is necessary to take into consideration that general international law does not establish individual, but collective responsibility for the acts concerned, and that the acts for which the guilty persons shall be punished are acts of 
State-that is, according to general international law, acts of the government or performed at the government's command or with its authorization. ${ }^{8}$

The legal meaning of the statement that an act is an act of State is that this act is to be imputed to the State, not to the individual who has performed the act. If an act performed by an individualand all acts of State are performed by individuals-must be imputed to the State, the latter is responsible for this act; and that means, so far as general international law is concerned, that collective responsibility takes place, constituted by reprisals or war, the specific sanctions of international law. If an act is to be imputed to the State and is not to be imputed to the individual who has performed it, the individual, according to general international law, is not to be made responsible for this act by another State without the consent of the State whose act is concerned. As far as the relationship of the State to its own agents or subjects is concerned, national law comes into consideration. And in national law the same principle prevails: an individual is not responsible for his act if it is an act of State, i.e., if the act is not imputable to the individual but only to the State. ${ }^{9}$ The

81 Oppenrem, op. cit. suppa note 4, at 274 , defines a State's "own actions" as "its government's actions, and such actions of the lower agents or private individuals as are performed at the Government's command or with its authorization."

${ }^{9}$ This rule, it seems, is not without exceptions. An individual who in his capacity as organ of the State has performed an illegal act may be made responsible for it. Thus, according to the law of some States, a Cabinet minister, and even the Head of State, may be accused and punished for having violated the constitution by one of his acts. But when the act is declared by the competent authority to be illegal with regard to the State's own law, it ceases to be an act of State-that is to say, the act can no longer be imputed to the State, whether it be annulable or not. To impute to the State an act that by the competent authority is declared to be illegal with regard to the State's own law is incompatible with the fact that the State, conceived of as an acting person, is but the personification of this law-i.e., the national legal order (or, what amounts to the same, the personification of the community constituted by this legal order). Within national law an act performed by an individual can be imputed to the State only on the basis of a legal rule; iniputation of an act to the State is subsunption of the act under a specific rule of law; and an individual can be considered as organ of the State only insofar as he performs acts imputable to the State. If an act is considered to be illegal with regard to the law of the State, it is hardly possible to interpret this act as act of State; and within national law the predicate "act of State" is a specific interpretation of an act performed by an individual. The State can do no wrong with regard to its own law, although the State can well do wrong with regard to international law. According to international law, "act of State" is any act perforned by the Governinent, at its command or with its authorization, regardless of the question of whether the act is legal or illegal according to national law and consequently imputable or not imputable to the State according to this law. "Act of State" in the sense of international law means the specific collective responsibility of the State established by general international law. 
other State, injured by such an act, can, without violating international law, make only the State whose act constitutes the violation of international law responsible for the act and the injured State may resort to reprisals or war against the responsible State. But prosecution of an individual by courts of the injured State for an act which, according to international law, is the act of another State, amounts to exercising jurisdiction over another State; and this is a violation of the rule of general international law that no State is subject to the jurisdiction of another State. Since the legal existence of a State manifests itself only in acts of individuals which, according to international law, are acts of State, the generally accepted rule that no State can claim jurisdiction over another State means that no State can claim civil or criminal jurisdiction over the act of another State. The immunity from the jurisdiction of another State is not, as this principle is usually.formulated, attached to the very "person" of the State-the "person" of the State is a juristic construction-but to the acts of the State as the acts performed by the government, at its command or with its authorization. The generally recognized principle that the courts of a State are not competent with regard to another State means that the courts of a State are not competent with regard to the acts of another State. Consequently, this principle applies not only where the defendant is expressly designated as the "State X" or the "person" of State X, but also where the defendant is an individual sued personally for an act performed by him as an act of State $X .^{10}$ The collective responsibility of a State for its own acts excludes, according to general international law, the individual responsibility of the person who, as a member of the government, at the command or with the authorization of the government, has performed the act. ${ }^{11}$ This is a consequence of the immumity of the

10 In the Report adopted by the Committee of Experts for the Progressive Codificacation of International Law at its third session, March-April, 1927, Rapporteur Matsuda, (Publications of the League of Nations, Legar, 1927, V, 9) 22 Supp. Am. J. Int. LAW 119, it is said: "The inability of courts to exercise jurisdiction in regard to a sovereign act of a foreign government . . . should apply where the defendant is sued personally for acts done by him in his capacity as a public official-though he no longer retains that capacity at the time of the proceedings-or under powers conferred upon him by a foreign State."

11 In the famous case of McLeod (nember of a British force sent in 1837 into the territory of the United States for the purpose of capturing the Caroline, arrested in 1840 in the State of New York, and indicted for the killing of an American citizen on the occasion of the capture of the Caroline), Mr. Webster, Secretary of State, to Mr. Crittenden, Attorney General, March 15, 1841: "All that is intended to be said at present is, that, since the attack on the Caroline is avowed as a national act, which may justify 
State from the jurisdiction of another State. This rule is not without exceptions but any exception must be based on a special rule of customary or conventional international law restricting the former. ${ }^{12}$

In this respect there exists no difference between the Head of State and other State officials. ${ }^{13}$ That a Head of State is not individually responsible to another State for acts performed by him in his capacity as organ of his State is not due to the personal privilege of exemption from criminal and civil jurisdiction of another State granted to Heads of State by general international law. Non-

reprisals, or even general war, if the Government of the United States, in the judgment which it shall form of the transaction and of its own duty, should see fit so to decide, yet that it raises a question entirely public and political, a question between independent nations; and that individuals connected in it cannot be arrested and tried before the ordinary tribunals, as for the violation of municipal law. If the attack on the Caroline was unjustifiable, as this Government has asserted, the law which has been violated is the law of nations; and the redress which is to be sought is the redress authorized, in such cases, by the provisions of that code." Cf. 2 MOORE, A DIGEst of INTERnational LAW (1906) \$179.

12 See infra p. 552.

13 In the memorandum of the American members of the Commission on Responsibilities established at the close of the first World War by the Preliminary Peace Conference (1920) 14 Aar. J. INr. LAw 136, it is said that "Proceedings . . . against an individual in office" are "in effect" proceedings "against the State." The American members of the Commission on Responsibilities advanced this argument to justify their opposition against the intention to bring Wilhelm II to justice before an international Tribunal. They refused to subject a Chief of State "to a degree of responsibility hitherto unknown to municipal or international law." (p. 135) In their memorandum they declared: "His [the Chief's of State] act may and does bind his country and render it responsible for the acts which he has committed in its name and its behalf, or under cover of its authority; but he is, and it is submitted that he should be, only responsible to his country.... The law to which the Head of the State is responsible is the law of his country, not the law of a foreign country or group of foreign countries. ..." In another passage of the memorandum it is said (p. 148) "that Heads of States are, as agents of the people in whom the sovereignty of any State resides, responsible to the people for the illegal acts which they may have committed, and that they are not and should not be made responsible to any other sovereignty ... ; that the essence of sovereignty consists in the fact that it is not responsible to any foreign sovereignty; that in the exercise of sovereign powers which have been conferred upon him by the people, a nonarch or IIead of State acts as their agent; that he is responsible only to them; and that he is responsible to no other people or group of people in the world." Apart from the confusion of the doctrine of popular sovereignty (not applicable to some monarchical States) with the legal principle of State sovereignty, and apart from the questionable statement that IIeads of States are always responsible to their people, the thesis advoeated by the American members of the Commission on Responsibilities: that a Head of State, acting as agent of his State, is not individually responsible to another State, is undoubtedly correct. This principle applies not only to Heads of States, but also to all individuals acting as agents of a State. If the State is sovereign, any agent of the State exercises the sovereignty of the State; and the principle that no sovereignty is responsible to another sovereignty is but a more general formulation of the rule that no State is subject to the jurisdiction of another State. 
responsibility of the Head of State for his acts of State is the consequence of the rule of international law that no State can claim jurisdiction, exercised by its courts, over acts of another State. The personal privilege of exemption from criminal and civil jurisdiction of another State granted by imternational law to Heads of State refers, in the first place, not to acts of State performed by a Head of State, but rather to acts committed abroad by a Head of State in his capacity as a private person. Consequently, the same privilege can be and is granted by international law to the wife of the Head of State who may never perform an act of State. The personal privilege of exterritoriality must be granted to a Head of State only as long as he is actually in office, not after he has been deposed or has abdicated, or his office has expired. For his act of State, however, he is individually not responsible to another State, even after his deposition, abdication, or expiration of office, since the act was performed when he was still in office; otherwise the act could not have been an act of State. Non-responsibility of the Head of State for his acts of State, based on the rule that no State can claim jurisdiction over the acts of another State, works also in the case where the Head of State has fallen into his enemies' hands as prisoner of war, even if his personal privilege of exterritoriality does not work because it is limited to the time of peace and does not apply in time of war. There is no sufficient reason to assume that the rule of general customary law under which no State can claim jurisdiction over the acts of another State is suspended by the outbreak of war, and consequently that it is not applicable to the relationship between belligerents. ${ }^{14}$

Exclusion of individual responsibility constitutes the difference which exists between the State's collective responsibility for its own acts, its "original" responsibility, and the State's collective responsibility for acts other than its own-namely, certain violations of international law committed by individuals not at the command or not done with the authorization of the government-the State's "vicarious" responsibility. This kind of responsibility of the State does not exclude the individual responsibility of the persons who have performed the acts constituting the violation of international law; on the contrary, their individual responsibility is implied by the collective responsibility of the State in so far as the latter is obliged by international law to punish these individuals and to compel them to repair the illegally caused damage. 
If individuals shall be punished for acts which they have performed as acts of State, by a court of another State, or by an international court, the legal basis of the trial, as a rule, must be an international treaty concluded with the State whose acts shall be punished, by which treaty jurisdiction over these individuals is conferred upon the national or international court. If it is a national court, then this court functions, at least indirectly as an international court. It is national only with respect to its composition, in so far as the judges are appointed by one government only; it is international with respect to the legal basis of its jurisdiction.

The law of a State contaims no norms that attach sanctions to acts of other States which violate international law. Resorting to war in disregard of a rule of general or particular international law is a violation of international law, which is not, at the same time, a violation of national criminal law, as are violations of the rules of international law which regulate the conduct of war. The substantive law applied by a national court competent to punish individuals for such acts can be international law only. Hence the international treaty must not only determine the delict but also the pumishment, or must authorize the international court to fix the punishment which it considers to be adequate. If a national court is authorized and if the national constitution obliges the courts to apply only norms created by the legislative (or other law-making) organ of the State, the norms of international law authorizing the State to punish individuals who, as organs of another State, have violated international law must be transformed into norms of the national law of the State of the jurisdiction of which these mdividuals are subjected by the treaty. An international treaty authorizing a court to punish individuals for acts they have performed as acts of State constitutes a norm of international criminal law with retroactive force; for the acts were at the moment when they were committed not crimes for which the individual perpetrators were responsible. There is no rule of general customary international law forbidding the enactment of norms with retroactive force, so-called ex post facto laws. But some State constitutions forbid it expressly and it is a principle of criminal law recognized by most of the civilized nations that no punishment must be attached to an act which was not legally punishable at the moment of its performance. Some writers, abandoning the positivist view, maintain that not only custom and treaties but also the general prim- 
ciples of law are to be considered as sources of international law..$^{14 a}$ This doctrine is very questionable and, even if accepted, does not exclude an international treaty authorizing a court to punish the persons morally responsible for the second World War. The principle forbidding the enactinent of norms with retroactive force as a rule of positive national law is not without many exceptions. Its basis is the moral idea that it is not just to make an individual responsible for an act if he, when performing the act, did not and could not know that his act constituted a wrong. If, however, the act was at the moment of its performance morally, although not legally wrong, a law attaching ex post facto a sanction to the act is retroactive only from a legal, not from a moral point of view. Such a law is not contrary to the moral idea which is at the basis of the principle in question. This is in particular true of an international treaty by which individuals are made responsible for having violated, in their capacity as organs of a State, international law. Morally they were responsible for the violation of international law at the moment when they performed the acts constituting a wrong not only from a moral but also from a legal point of view. The treaty only transforms their moral into a legal responsibility. The principle forbidding ex post facto laws is-in all reason-not applicable to such a treaty.

\section{VI.}

In its report presented to the Preliminary Peace Conference on March 29, 1919, the Commission on the Responsibility of the Authors of the War and Enforcement of Penalties distinguished "two classes of culpable acts: (a) Acts which provoked the world war and accompanied its inception; (b) Violations of the laws and customs of war and the laws of humanity." The Commission advised that "the acts which provoked the war' should not be charged against their authors and made the subject of proceedings before a tribunal." Nevertheless, the Peace Treaty of Versailles stipulated in Article 227:

14a In the Report of the Subcommittee on the Trial and Punishment of War Criminals appoimted by the House of Delegates of the American Bar Association, July 20, 1943, published in (1943) 37 AMr. J. INT. LAw 663, it is said: "The principles of criminal law generally accepted among civilized nations are also a proper source of international law. If doubts arise, there should be prompt agreement upon a restateunent of what the pertinent law has been and the proceedings and penalties which it admits. Caution should be exercised to exclude anything which may fairly be denounced as legislation after the event." 
"The Allied and Associated Powers publicly arraign Wilham II of Hohenzollern, formerly German Emperor, for a supreme offence against international morality and the sanctity of treaties. A special tribunal will be constituted to try the accused, thereby assuring him the guarantees essential to the right of defence. It will be composed of five judges, one appointed by each of the following Powers: namely, the United States of America, Great Britain, France, Italy, and Japan."

The formula "for a supreme offence against international morality and the sanctity of treaties" is insincere and inconsistent. The true reason for the ex-Kaiser's demanded submission to a criminal court was that he was considered the main author of the war, and resorting to this war was considered a crime. Article 227 speaks of "an offence of international morality" in order to avoid speaking of a violation of international law. But if a legal norm-such as a norm established by an international treaty-attaches pumshment to an offense of morality, a punishment to be inflicted upon the offender by a court, the offense assumes ex post facto the character of a violation of law. Article 227 speaks also of an offense against the "sanctity of treaties." This means a violation of treaties, which is a delict according to international law.

The main reasons for the negative advice of the Commission on Responsibilities were, in the first place, according to the opmion of the Commission, that "a war of aggression may not be considered as an act directly contrary to positive law, or one which can be successfully brought before a tribunal such as the Commission is authorized to consider under its terms of reference"; in the second place, that "any inquiry into the authorship of the war must, to be exhaustive, extend over events that have happened during many years in different European countries, and must raise many difficult and complex problems which might be more fitly investigated by historians and statesmen than by a tribunal appropriate to the trial of offenders against the laws and customs of war."

The statement that a war of aggression is not an act contrary to positive law is, at least, very doubtful. The principle of bellum justum is considered by outstanding authors as a rule of positive international law. It is just the Peace Treaty of Versailles and the other Peace Treaties of 1919-20 which confirm the doctrine of bellum justum.

The Peace Treaties did not oblige the vanquished States to pay a war indemnity, but rather to make reparation. The obligation of reparation is considered to be a consequence attached by general in- 
ternational law to a violation of international law. That the Peace Treaties substitute the obligation of reparation, established by general international law and merely specified by the Peace Treaties, for a war indemnity, presupposes that the damages inflicted by the war are considered to be illegally caused. This is the meaning of Article 231 of the Peace Treaty of Versailles establishing Germany's war guilt:

"The Allied and Associated Governments affirm and Germany accepts the responsibility of Germany and her Allies for causing all the loss and damage to which the Allied and Associated Governments and their nationals have been subjected as a consequence of the war imposed upon them by the aggression of Germany and her Allies."

The statement that the war was "imposed" upon the Allied and Associated Governments "by the aggression of Germany and her Allies" means that Germany and her Allies have violated international law by resorting to the war. Otherwise the obligation to repair the damage caused by the war would not be justifiable, since the damage would not have been illegally caused. Only on the basis of the bellum justum doctrine is a "war guilt" possible.

When the second World War broke out, the legal situation was different from that at the outbreak of the first World War. The Axis Powers were contracting parties to the Kellogg-Briand Pact by which resorting to a war of aggression is made a delict; and Germany has, by attacking Poland and Russia, violated, in addition to the KelloggBriand Pact, non-aggression pacts with the attacked States. Any inquiry into the authorship of the second World War does not raise problems of extraordinary complexity. Neither the questio juris nor the questio facti offers any serious difficulty to a tribunal. Hence, there is no reason to renounce a criminal charge made against the persons morally responsible for the outbreak of World War II. In so far as this is also a question of the constitutional law of the Axis Powers, the answer is simplified by the fact that these States were under more or less dictatorial regimes, so that the number of persons who had the legal power of leading their country into war is in each of the Axis States very small. In Germany it is probably the Fuehrer alone; in Italy, the Duce and the King; and in Japan, the Prime Minister and the Emperor. If the assertion attributed to Louis XIV "l'Etat c'est moi" is applicable to any dictatorship, the punishment of the dictator amounts almost to a punishment of the State. Another ques- 
tion is whether it will be actually possible to lay hold on these persons in order to bring them to justice.

\section{VII.}

War crimes in the narrower sense of the term are acts by which rules of international law regulating the conduct of war are violated. They are committed by members of the armed forces of the belligerents. As pointed out, the term "war crime" sometimes comprises also all hostilities in arms committed by individuals who are not members of the armed forces, acts of illegitimate warfare committed by private individuals who take up arms against the enemy, and further, espionage, war treason, and all marauding acts. ${ }^{15}$ Most of the acts constituting violations of the rules of warfare are at the same time violations of general criminal law, such as murder, pillage, theft, incendiarism, violence, rape, and the like. "The principle," says Garner, ${ }^{16}$ "that the individual soldier who commits acts in violation of the laws of war, when these acts are at the same time offenses against the general criminal law, should be liable to trial and punishment, not only by the courts of his own State, but also by the courts of the injured adversary in case he falls into the hands of the authorities thereof, has long been maintained. ..." The acts in question are considered to be punishable by the courts of the injured State because they constitute crimes according to its national law. But almost all the acts of war, also the acts of legitimate warfare, constitute crimes according to criminal law, since acts of war are acts of forcible deprivation of life, liberty, property, forbidden by criminal law. Nevertheless, acts of legitimate warfare are not punishable by the courts of the State whose subjects are the victims. A State which punishes for murder or incendiarism soldiers who, as members of the armed forces of the enemy, have killed in battle soldiers of the armed forces of the State claiming jurisdiction, or have burned down houses of the latter's citizens, openly violates international law. What deprives these acts of their criminal character? What excludes the criminal responsibility of the individuals who have performed these acts? The usual answer is that these acts are in conformity with international law which permits the belligerants to deprive forcibly the members of the armed forces of the enemy of their lives and freedom, to destroy property of their citizens, and the like. They are "legitimate"

15 See supra p. 531.

162 Garner, INtrernational Law aNd the Wordd War (1920) 472. 
acts of war only when they are performed in conformity with international law; "... otherwise they are murder or theft as the case may be and their authors are liable to punishment as criminals."17 The fact that an act is permitted by international law deprives the act of its criminal character; the fact that an act is forbidden by international law maintains its criminal character according to national law.

This doctrine is not maintainable. The statement that acts of legitimate warfare are "permitted" by international law means that international law does not "forbid" them. Legally permitted is what is legally not forbidden; the statement that international law does not forbid those acts means that international law does not attach to those acts any sanction. A conduct is legally forbidden if it is the condition of a sanction. The negative fact that international law does not forbid certain acts because it does not attach sanctions to them cannot exclude the legal possibility of national law attaching sanctions to those acts and thus forbidding them. National law attaches sanctions to many acts which are not forbidden-and that means "permitted" (in the negative sense of the term)-by international law, without violating international law. An individual, citizen of State A, when committing theft against an individual, citizen of State $B$, in the territory of State A, does not violate international law. The latter does not forbid such an act and does not make State $A$ responsible for it. But State $B$ does not violate international law by punishing the thief when he falls into the hands of its authorities. In fact, that an act is not forbidden (and hence "permitted" in a negative sense) by international law does not deprive the act of its criminal character, if the act is made a crime by national law.

However, the term "permission" may have a positive sense. It may mean "authorization". The law "authorizes" an individual by conferring upon the individual a legal power, a "right" in the techmical sense of the term. The law "authorizes" an individual to perform an act to which the law attaches a legal effect: the legal effect intended by the acting individual. Killing, wounding, capturing of human beings in war are not acts by which legal effects are intended, such as by a legal transaction or an action brought before a court. They are "permitted" by international law only in the negative sense of the term. This is especially true if war, as many writers assume,

17 Ibid. at 473, following Renault, De l'application du droit pénal aux faits de guerre (1918) 25 Revue Génírale de Droit Internationac Public 10. 
is not a legal action authorized by international law as reaction against an international "delict", that is, as "just war", and otherwise forbidden as a delict. It is squarely on the basis of the bellum justum theory that the fallacy of the doctrine can be provedthat an act which is permitted by international law must not be punished according to national law, whereas as a logical consequence, an act which is forbidden by international law may be punished according to national law. Normal acts of warfare performed by members of the arined forces involved in an unjust war forbidden by general international law or by a particular treaty, such as the Kellogg-Briand Pact, cannot be considered to be "permitted", neither in a negative nor in a positive sense of the term, since the war as such is forbidden and, consequently, all the single acts which in their totality constitute the war inust be considered as forbidden..$^{18}$ Nevertheless, a State which punishes a member of the armed forces of the enemy guilty of an unjust war for having killed in battle a member of the armed forces of the State claiming jurisdiction, violates international law. The fact that the act is forbidden by international law does not maintain the crimmal character which it may have according to national law.

That a State violates international law if it punishes as a criminal, according to its national law, a member of the armed forces of the enemy for an act of legitimate warfare, can be explained only by the fact that the State by so doing makes an individual responsible for an act of another State. According to international law, the act in question must be imputed to the enemy State and not to the individual who in the service of his State has performed the act. It cannot be considered as a crime of the individual because it must not be considered as his act at all. General international law, as a rule, forbids a State to make a person individually responsible for an act committed as an act of another State. Consequently, the individual performing an act of war as an act of his State must not be punished for this act by the enemy State, even if the act constitutes a violation of international law, if the war as such is forbidden or the act in itself

18 The distinction between acts of "legitimate" and acts of "illegitimate" warfare performed in a war forbidden by general or particular international law is possible only insofar as an act of "legitimate" warfare constitutes only the violation of the rule forbidding war, whereas an act of "illegitimate" warfare constitutes a violation not only of that rule but also of a rule concerning warfare. It is quite possible that by one and the same act two different legal rules are violated, and that two different rules attach to one and the same act two different sanctions. 
constitutes a so-called war crime. For an act performed by an individual at the command or with the authorization of his government is an act of State, even if it constitutes a violation of international law; and responsibility for such a violation of international law rests, according to general international law, upon the State collectively, not upon the individual who in the service of his State has performed the act. ${ }^{19}$ Otherwise no violation of international law in general and the rules regarding warfare in particular by States would be possible. "Violations of rules regarding warfare," writes Oppenheim, ${ }^{20}$ "are war crimes only when committed without an order of the belligerent government concerned. If members of the armed forces commit violations by order of their government"-and that means: if the violation of the rules of warfare has the character of an act of State"they are not war criminals, and may not be punished by the enemy; the latter may, however, resort to reprisals." Reprisals are specific sanctions establishing the collective responsibility of the State. If the war crime is an act of State, the collective responsibility of the State for this act, as a rule, excludes individual responsibility for it. ${ }^{20 a}$ The fact that the act is forbidden by international law does not maintain the criminal character which it may have according to national law. The statement that if an act is forbidden by international law as a war crime, the perpetrator personally may be punished by the injured State according to its national law if he falls in the hands of its authorities as prisoner of war, is correct only with the restriction that the act is not an act of the enemy State, and if it is an act of the enemy State, only with the latter's consent.

This is the consequence of the generally recognized principle that no State has jurisdiction over the acts of another State. Suspension of this principle must not be considered as one of the effects of the outbreak of war upon the relations between the belligerents. The

19 Bellot, A Permanent International Criminal Court, The International Law Assoctation, Report of tHe Thirty-First Conference (1923) vol. I, 73. "An order by the ... Government cannot make that lawful which is unlawful by International Law." That is true, but the fact that an act is "unlawful by International Law" does not necessarily constitute the individual responsibility of the perpetrator. As a rule, it constitutes only the collective responsibility of the State whose government issued the command.

202 OPPENhEDS, op. cit. supra note 3 (1st to 5th eds.) \$253.

20a Verdross, VoELKERREcHT (1937) 298 correctly formulates the rule concerned as follows: "Punishment [of a prisoner of war for a war crime] is madmissible if the act has not been performed of [the accused person's] own account but can be imputed to his home State." An act which is to be imputed to the State is an act of State. 
rules of general customary international law remain, in principle, in force in time of war. ${ }^{21}$ The principle according to which the collective responsibility of the State for its acts excludes the mdividual responsibility of the perpetrator is by its very nature destined to play an important role not only in time of peace but also in time of war, since war itself is one of the most characteristic acts of State and the principle in question a necessary protection of the individuals who by national law are obliged, as organs of their State, to perform this act. However, the rule of general customary international law granting acts of State immunity from the jurisdiction of another State has some exceptions, as has been pointed out. Does the rule that prisoners of war be subjected to the law and jurisdiction of the captor State constitute, with respect to violations of the rules of warfare, a restriction to the principle of the immunity of the State from the jurisdiction of another State? That is the question. Without examining the problem with reference to the principle of the State's immunity from the jurisdiction of another State, some writers maintain that the fact that a war crime is committed as an act of State does not deprive the act of its character as crime punishable by the injured State accord" ing to its national law. ${ }^{22}$ This view, however, is more than questionable. Criminal jurisdiction of the captor State over war prisoners is a restriction of the rule according to which the members of the armed forces of a foreign State are exempt from the jurisdiction of the State on the territory of which they are staying. Since jurisdiction over prisoners of war is based on a restriction of another rule, a restrictive interpretation of the rule conferring jurisdiction over prisoners of war upon the captor State is adequate. There is no reason to interpret the rule concerned as a restriction to still another rule-namely, the rule concerning the immunity of a State from the jurisdiction of another State, and to allow the captor State to punish a prisoner of war for acts committed as acts of his State without the latter's consent. Jurisdiction of the State over individuals who, as prisoners of war, are staying on its own territory can also be based on the general principle that any State has exclusive jurisdiction over all persons and things within its territory. Among the restrictions to this principle

21 VERDROSS, ibid. at 293.

22 This view is adopted also in the 6th edition of 2 OPPENHEDA, INTERNATIONAL LAW (1940) $\$ 253$, edited by H. Lauterpacht. Here it is said of the opinion advocated in all the five foregoing editions: "It is difficult to regard it as expressing a sound legal principle." In the sixth cdition the fact that a war crime is an act of State is not clearly distinguished from the fact that it is performed at superior command. See infra p. 556. 
the rule regarding the immunity of a foreign State stands certainly in first place. A State cannot elude this rule of general international law by declaring the act of a foreign State a crime in the sense of its (the former's) national law and prosecute the individual perpetrator of the act if he falls into the hands of its authorities. For, prosecution of an individual for an act that has been performed as an act of a foreign State is directed against the foreign State itself.

A clear exception is established by the rule regarding espionage and war treason. General international law authorizes the State against which acts of espionage and war treason had been committed to punish the perpetrators as war criminals, even if the acts concerned have been committed at the command or with the authorization of the enemy government. In contradistinction to other war crimes, the States are not obliged to prevent and to punish such acts if committed in their own interest against the enemy. If they use them in their own interest, they do not violate international law and, consequently, are not responsible for them. In these cases, general international law establishes only individual responsibility of the perpetrators, no collective responsibility of the States, even if the act has the character of an act of State.23

In so far as individual responsibility for violation of the rules of warfare committed as acts of State is, according to general international law, excluded, punishment for such acts by a national court of the enemy or by an international court without violation of international law is possible only with the consent of the home State of the delinquent-that is to say, on the basis of an international treaty concluded with the State for whose acts the individual perpetrators shall be punished. Only by such treaty can jurisdiction over the indi-

23 Cf. 2 OPPENHETM, op. cit. supra note 3, at 328, 456; VeRDRoss, op. cit. supra note 20a, at 298; KUN2, KRIEGSRECHT UND NEUTRALTTAETSRECHT (1935) 67. If it must be admitted that international law authorizes the States injured by espionage or war treason to punish the perpetrators, espionage and war treason must be considercd as "crimes" and consequently, as "forbidden" by international law. For de lege lata, the only legal criterion of a crime as a conduct "forbidden" by law is that law-national or international-attaches to the conduct a punishment. The quality of being a crime or, in a more general sense, a delict, is a thoroughly relative one. A conduct is a delict in relation to the sanction (and especially the pumishment) attached to it by a legal order, and only in relation to the legal order attaching the sanction to the conduct concerned. The fact that espionage and war treason counmitted against the enemy are not delicts and consequently not forbidden according to the law of the State in whose interest they are committed, is quite compatible with the fact that the same acts are dehicts and consequently forbidden by the law of the State against which they are committed, and by international law in relation to the injured State. 
viduals concerned be conferred upon a national court of the enemy or an international court. The norm of conventional international law establishing their individual responsibility has retroactive force.

An international treaty as the legal basis of trials of war criminals is necessary also, if prisoners of war shall be tried after the conclusion of peace for violation of the rules of warfare not committed as acts of State. For, after the conclusion of peace, all prisoners of war must be released according to general international law as well as the Geneva Convention of 1929. Any restriction of this rule is possible only with the consent of the home State of the prisoner. It stands to reason that the home State of the war criminals has jurisdiction over them, too. The jurisdiction of the captor State over war prisoners for war crimes not committed as acts of State is only a concurrent one. Whereas the captor State is authorized by international law to punish members of the armed forces of the enemy (as prisoners of war) for war crimes, the home State is obliged to punish his own war criminals; and the injured State has a right to demand the punishment.

Article 3 of the 1907 Hague Convention respecting the Laws and Customs of War on Land states: "A belligerent party which violates the provisions of the said Regulations (annexed to the Convention) shall, if the case demands, be liable to pay compensation. It shall be responsible for all acts committed by persons forming part of its armed forces." That means that a belligerent State is not only responsible for violations of the rules of warfare committed as its own acts, but also for violations of these rules committed by members of its armed forces if the acts concerned have not the character of acts of State. It is this responsibility of the belligerent State which implies the duty to punish its own war criminals.

\section{VIII.}

Most of the writers on international law maintain that war crimes constitute only penal offenses against national law, and that they have only "municipal" character, since international law does not provide punishment of the offenders. ${ }^{24}$ This statement is not correct. If the violation of the international rules of warfare constitute acts of State, they have, according to present positive law, no "penal" but an exclusively international character. If they do not constitute acts

24 Cf. Manner, The Legal Nature and Punishment of Criminal Acts of Violence Contrary to the Laws of War (1943) 37 AM. J. INT. LAw 407. 
of State, and if they are at the same time crimes according to national law, they have a double character; they are penal offenses against international and at the same time against national law. General international law, it is true, does not directly determine the penalty to be inflicted upon the criminal. But international law obliges the States whose subjects have, as members of their own armed forces, violated the law of warfare, to punish the criminals; and general international law authorizes the belligerents to punish an eneiny subject who has fallen into the hands of their authorities as prisoner, of war for having violated, prior to his capture, the laws of warfare. It is with respect to this authorization to punish enemy war criminals, that war crimes are usually defined as "such hostile or other acts of soldiers or other individuals as may be punished by the eneiny on capture of the offenders." 25 This definition is not quite correct since it refers only to war crimes in their relation to the enemy and ignores the fact that war crimes are delicts also in relation to the State whose subjects have committed the crimes, that these crimes are directly deterinined by international law, and that the home State of the delinquents is obliged by-international law (not only authorized as is the eneiny) to pumsh the criminals. By obliging the States to punish their own war criminals and by authorizing the States to punish the enemy war criminals, international law provides, at least indirectly, for punishment of war criminals. It leaves to national law to specify the penalty; even death penalty is not excluded by international law. Consequently, it is incorrect to speak of "absence of international war crimes." ${ }^{26}$ The first mentioned obligation of the States is but a consequence of their general obligation to execute international law within the sphere of validity of their own legal orders. It is expressly stipulated, for instance, by Article 1 of the Hague Land Warfare Convention of 1899 and 1907, by Article 8 of the Red Cross Convention of 1906, by Article 29 of the Red Cross Convention of 1929, and by Article 21 of the Hague Convention of 1907 concerming Adaptation of the Principles of the Geneva Convention to Maritime Warfare. The national criminal laws which attach penalties to war crimes, i.e., to acts forbidden by the international law of warfare, are enacted in fnlfillment of the State's obli-

252 OPPENHEIT, op. cit. supra note 3 , at 451.

26 Manner, op. cit. supra note 24, at 408 says: "Neither individual nor State can incur a criminal liability under international law of war." Only the State does not incur a criminal liability under actual international law. The individual incurs, at least indirectly, a criminal liability under international law. 
gation to enforce the international law within the State's sphere of power. The application of national law to the war criminal is at the same time execution of international law. The national law is an internediate stage made necessary by the State constitution authorizing the courts to apply only norms created by the law-making organs of the State. If no such constitutional restriction exists, or if, according to the constitution, international law is considered part of the national law, a direct application of the international rules of warfare by the courts of the State is possible. Since, however, these rules do not specify the punishment, an act of national law determining the penalties for war crimes is always necessary if these war crimes do not constitute at the same time ordinary crimes according to the criminal law of the State. ${ }^{27}$

If the crimes in question would constitute merely offenses of national law, if their punishnent were not application of international law, then it would hardly be possible to speak of war crimes. They are war crimes only insofar as they constitute violations of the rules of warfare, and these rules are, in the first place, nornis of international law. National criminal law attaches penalties to ordinary crimes, such as murder, theft, and the like. If a code of military criminal law attaches penalties to the killing of the wounded, refusal of quarter, making use of poisoned arms, pillage by members of the armed forces, and the like, it does so in order to enforce the norms

27 Schwarzenberger, War Crimes and the Problem of an International Criminal Court (1924) Czechoslovak Yearbook of International Law 70. "International law automatically authorizes the death penalty conceming all war crimes and it cannot be presumed that any belligerent has waived the right to apply punishment in accordance with this international usage. If, therefore, a belligerent should prefer to apply its own criminal law to war crimes, it confers a favor to the war criminal: for any gradation of crimes and punishment . . . amounts to a self-limitation of the belligerent concerned." International law does not "automatically" authorize the death penalty for war crimes. It only does not exclude it. The question of whether or not a belligerent can apply directly the rules of international law of warfare, or must apply its own criminal law executing the rules of international law, depends on its constitution. The application of a belligerent's own criminal law is not a favor to the criminal, for the direct application of international law does not necessarily imply the infliction of the death penalty on the criminal. The specification of the penalty is, at any rate, an act of national law, since international law itself does not specify the penalty. As far as the determination of the penalty is concerned, a direct apphication of international law is impossible. International law answers only the question whether a certain act shall or may be connected with punishment, and leaves to national law to answer the question what punishment has to be attached to the act determined by international law. Consequently, the "gradation" of punishment does not amount to a "self-limitation" of the belligerent concerned, but is simply the exercise of discretion left to the State by international law. 
of international law forbidding these acts. In absence of such a code of national law and of the possibility of direct application of international law, so-called war criminals could be punished only for having committed ordinary crimes. The misuse of the Red Cross flag would never be made a crime by national criminal law if the latter had not the purpose of executing the Geneva Convention.

\section{IX.}

National courts which, on the basis of national law, try individuals for war crimes are confronted with a serious difficulty when the act which constitutes the war crime has been committed at superior command. This does not necessarily imply that the act is an act of State. It is an act of State only if the command itself is an act of State, and that is the case only if the command was issued by the government (Head of State, cabinet, member of cabinet, parliament), or issued at the command or with the authorization of the government. The fact that an act is an act of State constitutes a problem of general international $\mathrm{law}^{28}$ which, as a rule, excludes individual responsibility for an act of State. That an act is performed at a superior command, constitutes a problem of national criminal law. It is the problem whether the plea of superior command is to be admitted by national criminal law as a defense against prosecution of an individual, charged with a war crime, whether the perpetrator who executed the command, or only the individual who issued the command, can be made responsible and be punished for the act. Prosecution and punishment of an individual by a court of the enemy for an act which has the character of an act of State without the consent of the State responsible for the act is a violation of international law. Punishment of an individual for an act which has been performed at superior command may, or may not, be a violation of national law.

As to the admissibility of the plea of superior command, the different positive legal orders as well as the opinions of jurists differ. From a military point of view, the plea must certainly be admitted. Discipline is possible only on the basis of unconditional obedience of the subordinate to the superior, and the obedience of the subordinate has its necessary complement in the exclusive responsibility of the superior. Article 347 of the Basic Field Manual: Rules of Land Warfare (FM 27110), published by the War Department of the

28 Responsibility for acts of State is, of course, not only a problem of international but also of national law. See supra p. 539. 
United States in 1940 (after enumerating the possible offenses by armed forces) stipulates: "Individuals of the armed forces will not be punished for these offenses in case they are committed under the orders or sanction of their government or commanders. The commanders ordering the commission of such acts, or under whose authority they are committed by their troops, may be pumished by the belligerent into whose hands they may fall."

Some national legal orders do not admit the plea of superior command if the command itself is illegal and as such void $a b$ initio. The execution of a legal command can never be punished as a crime. If the command is issued as a general or individual norn by the government or at the basis of such a norm, the command is rarely illegal in the sense of being void $a b$ initio. The general or individual norm constituting the command is normally voidable only, not void $a b$ initio, even if not in conformity with a superior norm of national law. This is the case if the war crime has been committed under the sanction of an "unconstitutional" statute or an "illegal" decree of the government, or an "illegal" arıny regulation. As long as such a norm is not invalidated by the competent authority, it is valid; and as long as it is valid it has to be considered in relation to the individual who executes it as a legal command. Cases of absolute nullity (not mere annulability) of acts of Governnent are very rare. Besides, the legal power conferred by national law and, in particular, by the law of autocratic States like Nazi Germany, upon the government, and that means, upon the head of the State as commander-in-chief of the armed forces with respect to the conduct of war is almost unlimited. The government is nearly always in a position to justify its acts from the point of view of national law by the necessities of war. Consequently, it is difficult to repudiate the plea of superior command by the argument that the command was "illegal", in case the command has been issued by the government or is based on a command of the government. Illegality of the command as justification of repudiating the plea of superior command, if applicable, is almost restricted to cases of commands issued by relatively subordinate organs without authorization on the part of their government.

According to the law of some States, the plea of superior command can be rejected only if the command was manifestly and indisputably contrary to law. It is not sufficient that the command was objectively illegal. The command must be "universally known to everybody, included also the accused, to be without any doubt what- 
ever against the law." ${ }^{20}$ Such cases are obviously very rare, especially when the illegality of the command consists in a violation of international law. In this case the situation is totally different from that where the illegality of the command constitutes only a violation of general criminal law. Everybody knows, or is in a position to know, what the general criminal law of his country forbids. But is it really possible to assume that every soldier knows what international law forbids? Violation of international law is, according to the same international law, permitted as reprisal. This is of particular importance with respect to the rules of warfare, since the only possible sanctions provided by international law against a violation of these rules are reprisals. How can a soldier know that a command constituting a violation of the rules of warfare is not a reprisal and thus permitted? How can he consider such a command to be "without any doubt whatever" against the law? The idea of justice which is the basis of national criminal law and in particular the basis of military criminal law, is certainly not favorable to the prosecution of individuals who coinmitted war crimes in response to a superior command. Since most of the war crimes, the punishment of which is demanded, and in particular almost all the politically important war crimes, are committed at superior commands that can hardly be supposed to be inanifestly and undisputably illegal, national courts applying national criminal law are certainly not fitted for the punishment of war criminals which public opinion requests. Especially ill-fitted are the national courts of the accused. Those courts are still more inclined to admit the plea of superior command than are courts of the enemy. This has been proved by the famous trials of German war criminals after the first World War. ${ }^{30}$

29 Decision of the German Reichsgericht in Leipzig in the case of the "Llandovery Castle," quoted by MuLinss, The LeIPzTg Triars (1921) 131.

30 The most interesting case is the trial of Lieutenant Karl Neumann, Commander of a German submarine, who admitted that he had torpedoed and sunk the British hospital ship "Dover Castle". He pleaded that in so doing he merely carried out an order of the German Admiralty, his superior authority. With respect to this order the circumstances were as follows: The German Government came to helieve that the enemy Governments were utilizing their hospital ships, not only to aid wounded, sick and shipwrecked people, but also for military purposes, and that they were thereby violating international law. The German Government declared that it was compelled to restrict the navigation of enemy hospital ships. In an order of the Admiralty issued on March 19, 1917 , to the German Flotilla in the Mediterranean, which corresponded with a memorandum of the German Government of the same date directed to the enemy Governments, it was stated that hospital ships had to he reported at least six weeks previously and were to keep to a given course on leaving Greece. All other enemy hospital ships in 
$\mathrm{X}$.

According to a generally accepted view, mentioned above, a belligerent has jurisdiction over prisoners of war for war crimes com-

the Mediterranean were to be regarded as vssels of war and forthwith attacked. The accused, held the Court, was "of the opinion that the measures taken by the German Admiralty against enemy hospital ships were not contrary to international law, but were legitimate reprisals. . . . It is a military principle that the subordinate is bound to obey the orders of his superiors. This duty of obedience is of considerable importance from the point of view of the criminal law. Its consequence is that, when the execution of a service order involves an offence against the criminal law, the superior giving the order is alone responsible. The Admiralty Staff was the highest authority over the accused. He was in duty bound to obey their order in service matters. So far as he did that, he was free from criminal responsibility. Therefore he cannot be held responsible for sinking the hospital ship 'Dover Castle' according to orders."

The Court quoted Section 47 of the Gernan Military Penal Code, according to which a subordinate who acts in conformity with orders is also liable to pumishinent as an accomplice when he knows that his superiors have ordered him to do acts which involve a civil or military crime or misdemeanor. The Court stated: "There has been no case of this here. The accused accordingly sank the 'Dover Castle' in obedience to a service order of his highest superiors, an order which he considered to be binding. $\mathrm{He}$ cannot, therefore, be punished for lis conduct." MucLIns, op. cit. supra note 29, at 99 et seq.

Also very characteristic is the case of Lieutenants Ludwig Dithmar and Johann Boldt. They had been serving as officers on the German submarine U-86 under Captain Helmuth Patzig on the night of June 27, 1918. On that might Captain Patzig, with Lieutenants Boldt and Dithmar, torpedoed the British hospital ship "Llandovery Castle" and then fired upon the lifeboats containing nembers of the crew of the hospital ship who were attempting to escape after the "Llandovery Castle" had been sunk. Captain Patzig could not be brought to trial because he had taken refuge in the State of Danzig, which, at that time, was an independent State, and from which Germany announced it was unable to obtain his extradition. It was proved that the accused had participated in the torpedoing of the hospital ship under the orders of Captain Patzig. The three officers consulted together after the "Llandovery Castle" had been sunk and agreed that they would destroy all the witnesses to their act by sinking the hifeboats containing 234 survivors. The Court held that the defendants were not guilty of the torpedoing although it was a violation of international law, because they were acting under the orders of a superior. The Court, however, did find them guilty of the crime of aiding and abetting manslaughter in firing on the lifeboats. The Court declared: "It is true that according to the Military Penal Code, if the execution of an order in the ordinary course of duty involves such a violation of the law as is punishable, the superior officer issuing such an order is alone responsible. However, the subordinate obeying such an order is liable to punishment if it was known to him that the order of the superior involved the infringement of civil or military law. This applies in the case of the accused. Military subordinates are under no obligation to question the order of their superior officer, and they can count upon its legality. But no such confidence can be held to exist, if such an order is universally known to everybody, including also the accused, to be without any doubt whatever against the law. This happens only in rare and exceptional cases. But this case was precisely one of them, for in the present instance, it was perfectly clear to the accused that killing defenceless people in the lifeboats could be nothing else but a breach of the law." Ibid. at 107 et seq. 
mitted before capture. ${ }^{31}$ National military courts exercising jurisdiction over prisoners of war are confronted with the difficulty that it is, at least, doubtful whether military tribunals can prosecute enemy war criminals after the conclusion of peace. As pointed out, prisoners of war must be released at the end of the war, even if they have been sentenced for having committed war crimes and if their terms of imprisonment have not yet expired..$^{32}$ In any case, prisoners of war charged with war crimes but not yet tried and sentenced must be released..$^{33}$ In order to overcome this difficulty, it has been suggested "that the armistice agreement shall contain provisions for the surrender of the war criminals of the enemy in order to give the victorious Powers the opportunity to try the criminals through their national courts before the conclusion of peace." ${ }^{34}$ But it seems to be doubtful whether individuals surrendered by one belligerent to the other on the basis of an international treaty-the armistice agreement-are really "prisoners of war". Prisoners of war are, according to the definition given in Article 1, Section 2, of the Convention relating to the treatment of prisoners of war, signed at Geneva, July 27, 1929 , for prisoners captured in sea and air warfare, ". . p persons belonging to the armed forces of belligerents who are captured by the enemy in the course of operations of maritime or aerial war. . .." Persons extradited by one belligerent to the other in execution of a treaty of armistice can hardly be considered as captured in the course of military operations. The legal basis of the jurisdiction claimed over those persons by the enemy is not the rule of international law concerning jurisdiction over prisoners of war, but the international treaty by which the State whose subjects shall be tried consents to their trial by the enemy. By the provisions of the armistice agreement, jurisdiction over the persons in question is conferred upon the enemy. Since these persons are not war prisoners in the

31 Manner, op. cit. supra note 24 , at 434 , says: "Belligerents during war may . . . legitimately try and punish every enenry person charged with such an infraction on the rules of warfare, provided that the accused has been taken prisoner of war and that he is judged according to the law and procedure in force in the armed services of the captor, and provided, further, that the accused cannot plead act of State and superior orders and that the act itself has been condemned as a penal offense prior to its commission by legislations patterned on the generally accepted laws and customs of war."

32 HaII, A Treatise on International. Law (1924) \$135. Oppenheim maintains that a belligerent has the right to carry out the punishnent inflicted on a war criminal even beyond the duration of the war. $0 p$. cit. silpra note 3 , at 459.

33 Cf. Manner, op. cit. supra note 24, at 421 .

34 Suggestion of the Lord Chancellor in the House of Lords, October, 1942, mentioned by Manner, op. cit. supra note 24, at 433. 
strict sense of the term, the courts of the enemy are not compelled to terminate the trial before the conclusion of peace. The accused persons are in the same legal position as individuals extradited in conformity with a treaty of extradition in time of peace. From a legal point of view, there is no essential difference between such an armistice agreement and a peace treaty obliging the vanquished State to extradite persons accused of war crimes by the victorious State to the latter in order to be prosecuted and punished by its courts. By such a treaty, the legal obstacles can be removed which impede postwar jurisdiction of the enemy over war criminals, and especially his jurisdiction over war crimes which have the character of acts of State and for which the individual perpetrators can be made responsible by enemy (or international) courts, only with the consent of the State whose acts are concerned.

This seems to be the true function of Article 228 of the Peace Treaty of Versailles, which runs as follows: "The German Government recognizes the right of the Allied and Associated Powers to bring before military tribunals persons accused of having committed acts in violation of the laws and custonis of war. Such persons shall, if found guilty, be sentenced to punishments laid down by law." By choosing the term "recognizes", the authors of the Peace Treaty seem to have attributed to Article 228 a declaratory character only. But without the consent of the German Government given in Article 228, the military tribunals of the Allied and Associated Powers had no right to try persons for war crimes, after the conclusion of peace. Article 228 does not expressly include war crimes which have the character of acts of State. But the fact that it does not exclude thein, and that, according to its wording, the German Government agrees to the prosecution by enemy military tribunals of their nationals for all acts committed in violation of the laws and customs of war, Article 228 may be interpreted as the necessary consent of the German Government to the punishment of Germans for having coinmitted war crimes having the character of acts of State, as the establishment by particular international law of the individual responsibility of the persons concerned excluded by general international law. To avoid any doubt in this respect, it would be advisable to insert into a future international treaty conferring upon a national or international court jurisdiction over war criminals, an express provision including war crimes which have the character of acts of State. ${ }^{35}$ 
XI.

As to the question what kind of tribunal shall be authorized to try war criminals, national or international, there can be little doubt that an international court is much more fitted for this task than a national civil or military court. ${ }^{36}$ Only a court established by an international treaty, to which not only the victorious but also the vanquished States are contracting parties, will not meet with certain difficulties which a national court is confronted with. For, the treaty by which jurisdiction over war criminals is conferred upon the court cannot only establish individual responsibility for war crimes that have the character of acts of State, but can also exclude the plea of superior command if this should be necessary from the viewpoint of international justice. Only an international court-international not only with respect to its legal basis but also with respect to its composition-can be above any suspicion of partiality, to which national courts and in particular national military courts, inevitably are open. Trials of war prisoners conducted by nnilitary courts during war may induce the enemy to take retaliatory measures executed in the form of analogous trials, although reprisals against prisoners of war are forbidden by the Geneva Convention. Such detestable inisuse of the law can be avoided by transferring the punishment of war criminals

belligerent, the occupant seems to be in a position to establish a special tribunal in order to try subjects of the enemy, even members of its government, arrested after the armistice by the authorities of the occupant on the occupied territory (hence not considered to be prisoners of war) for having committed war crimes. This is the assumption on which MAX RADIN's THE DAY OF RECKONING (1943) is based. It is, however, doubtful whether the rules of general internation law regulating the rights and duties of the occupant are favorable to such a procedure.

36 Hyde, Punishment of War Criminals (1943) Proceedings of the AMrerican SOCtety of INTERnational LAw 39, 43, at its Thirty-seventh Annual Meeting held at Washington, says: "It is conceivable that the Allied Powers may prefer to remain severally free to try and punish such alien enemy actors as are surrendered to them by domestic tribunals empowered to pass judgment on the conduct of those individuals and to apply penalties. At first glance this would appear to be a simple and unobjectionable procedure, and one free from certain difficultié to be encountered in any other. If, however, recourse to this method were productive of wholesale convictions and the application of innumerable penalties, the prosecuting victors might have difficulty in convincing society at large that the courts employed for the purpose were other tban political tools; and the persons subjected to punishment unight be regarded abroad as well as at home as martyrs. .. . A court or courts composed solely of neutral nationals would more easily command respect for decisions adverse to the claims and defenses of accised persons, and unless unduly fettered by the terms of the relevant treaty, migbt prove to be highly useful as expositors of international law. Moreover, the willingness of the Allied Powers to test and establish their grievances before neutral judges would inspire a widespread and decent respect for their stand." 
to an international tribunal established after the conclusion of peace and consequently im a position to fulfill its task in an atmosphere which is not poisoned by the passions of war. Internationalization of the legal procedure against war criminals has the great advantage of making the punishnient, to a certain extent, uniform. If the war criminals are subjected to different national courts, as provided by Article 229 of the Treaty of Versailles, it is very likely that these courts will "result in conflicting decisions and varying penalties." 37

It is the jurisdiction of the victorious States over the war criminals of the enemy which the Three Power Declaration signed in Moscow

37 Bellot, op. cit. supra note 19, at 421. Art. 21 of the Statute of the International Penal Court, adopted by the 34th Conference of the International Law Association of 1926 (Rep. of the Conference, 118) runs as follows: "The jurisdiction of the Court shall extend to all charges of-(a) Violations of international obligations of a penal character committed by the subjects or citizens of one State or by a heimatlos against another State or its subjects or citizens, (b) violations of any treaty, convention or declaration binding on the States parties to the convention of (place) dated. day of which regulate the methods and conduct of warfare. (c) Violations of the laws and customs of war generally accepted as binding by civilized nations.-Without prejudice to the original jurisdiction of the Court as hereinbefore defined, the Court shall have power to deal with cases of a penal character referred to it by the Council or Assembly of the League of Nations for trial, or for inquiry and report.- In the event of a dispute as to whether the Court has jurisdiction the matter shall he settled by the decision of the Court." In the Report of the Permanent International Criminal Court Committee, International LAw Assoctation ThIRTY-Fourte REport (1926) 110, it is said: "The body of opinion supporting the creation of an International Criminal Court is very considerable. In a paper read to the Grotius Society in March, 1916, and published in the September number of the Nineteenth Century, Dr. Bellot suggested the establishment of such a Court. It was recommended by the British Committee of Enquiry into Breaches of the Laws of War, and such recommendation was endorsed by the International Commission on War Crimes appointed by the Versailles Conference by a majority of eight to one. This recommendation was, however, rejected by the Supreme Council. It was subsequently recommended by the Committee of Hague Jurists, which drafted the Statute for the Permanent Court of International Justice. It was advocated by Lord Phillimore and Dr. Bellot in papers read at the Buenos Aires Conference of the International Law Association in 1922. Both authors of these papers suggested that the jurisdiction of the Court should extend to non-military as well as military offenses. But tbe Conference linited it to the latter, and it was resolved 'That in the opinion of this Conference the creation of an International Criminal Court is essential in the interest of justice and the Conference is of the opmion that the matter is one of urgency." In 1926 the International Penal Law Association at its Conference held in Brussels suggested the conferring of criminal jurisdiction upon the Permanent Court of International Justice. At the International Conference on the Repression of Terrorism, held at the initiative of the Council of the League of Nations, at Geneva on November 1st to 16 th, 1937, a Convention for the Creation of an International Criminal Court for the trial of persons accused of acts of terrorism was sigued. See ProcezDINGs of THE INTERnattonal CONFerence on the Repression of Terrorssm, Series of League of Nations Publications V. Legal, 1938. V. 3. Cf. also Hudson, The Proposed International Criminal Court (1938) 32 Axr. J. Int. LAw 549 et seq. 
demands. The persons who have committed war crimes shall ". . be brought back to the scene of their crimes and judged on the spot by the peoples whom they have outraged." War crimes which "have no particular geographical localization" shall be punished by ". . . joint decision of the Governments of the Allies." It is quite understandable that during the war the peoples who are the victims of the abominable crimes of the Axis Powers wish to take the law in their own hands in order to punish the criminals. But after the war will be over our minds will be open again to the consideration that criminal jurisdiction exercised by the injured States over enemy subjects is considered by the peoples of the delinquents as vengeance rather than justice and is consequently not the best means to guarantee the future peace.

The punishment of war criminals should be an act of international justice, not the satisfaction of a thirst for revenge. It does not quite comply with the idea of international justice that only the vanquished States are obliged to surrender their own subjects to the jurisdiction of an international tribunal for the punishment of war crimes. The victorious States, too, should be willing to transfer their jurisdiction over their own subjects who have offended the laws of warfare to the same independent and impartial international tribunal. ${ }^{88}$ Only if the victors submit themselves to the same law which they wish to impose upon the vanquished States, will the idea of international justice be preserved. And it is, after all, for the maintenance of international justice that the United Nations are waging this war. As far as the penalties are concerned, the international treaty establishing the jurisdiction of the court shonld authorize the latter to inflict upon the guilty person the penalty provided by the criminal law of his own State. This applies to war crimes in the narrower sense of the term. If the court has jurisdiction over persons who, in their

38 Hyde, op. cit. supra note 36 says: "Should the work of any tribunal be confined objectively to the trial and possible conviction of members of the Axis forces, or should it embrace members of the Allied forces charged by their enemies with committing offenses against the laws of war? The matter needs careful thought. Confidence in the high purpose of the Allied Powers would doubtless be enhanced in every quarter if the courts to be employed were given a comprehensive jurisdiction to pass upon the conduct of any person of any nationality, regardless of the beligerent on whose side he served. If, however, a member of an Allied force were found guilty, as charged, the matter of inflicting a penalty would call for definite arrangement. An Allied Power might be expected to dechine to agree to surrender a convicted member of its forces to an Axis Power for punishment under its auspices. Doubtless an Allied Power would insist on a scheme for the punishment of members of its own services by its own agencies within its own domain, if they were to be subjected to prosecution." 
capacity as organs of a State, have violated international law by resorting to or provoking war, the treaty establishing the court may determine the penalties or authorize the court to fix them according to its discretion.

\section{XII.}

The punishment of war crimes by an international tribunal, and particularly the punishment of crimes which have the character of acts of State, would certainly meet with much less resistance, since it would hurt national feelings much less if it were to be carried out within the framework of a general reform of international law, the aim of which is to complete the collective responsibility of States for violations of international law by the individual responsibility of the persons who, as agents of the State, have committed the acts by which international law has been violated. ${ }^{39}$ Such a reform can be carried out successfully only on the basis of an international treaty constituting a League of States whose main organ is a court endowed with compulsory jurisdiction. The Covenant of the League must oblige the members to submit to the court all their disputes without any exception, so that war is permitted only as a collective action organized by the Covenant-that is to say, as a sanction executed by the League. Compulsory jurisdiction of international disputes is an essential condition of any further progress of the legal technique of international law, and the establishment of individual responsibility in the relationship between States as a general rule is probably the most

30 The Conference of the International Penal Law Association held at Brussels, 1926, passed unanimously the following resolutions: "1. That a criminal jurisdiction be granted to the Permanent Court of International Justice. 2. That it be consulted, regarding the settlement of conflicts of jurisdiction, judicial or legislative, which may arise between different States. ... 3. That the Criminal Permanent Court shall hear all cases for penal responsibilities agaimst States consequent upon an unjust aggression and for violations of International Law. It shall impose penal sanctions and measures for security upon the offending State. 4. That the Permanent Court shall hear cases of individual responsibilities which may arise from the crime of aggression as well as crimes and accessory crimes or misdemeanors and all violations of international law committed in time of peace or in time of war and particularly Common Law offences which by reason of the nationality of the victim of the presumed offenders can be considered in this by other States as being international offences and as constituting a menace to the peace of the world. 5. That the Perinanent Court shall have the jurisdiction over individuals who may have committed crimes or offenses which cannot be submitted to the jurisdiction of a particular State, owing to the fact that the territory on which such offenses have been committed is unknown or where the sovereignty is disputed." (1926) 3 Revue INTERNattonale DE DROIT PENAL, 466. 
radical step possible within a legal order which shall maintain the character of international law. ${ }^{10}$

The attempt to establish individual responsibility in all the international relations of States by providing punishment of guilty persons suggests the question as to the conditions on which the act constituting the violation of international law has the character of a punishable crime im the strict sense of the term. The question is already answered if the act, as in the case of war crimes, is at the same time a violation of national criminal law. If, however, the act is not a "crinie" according to national criminal law, its punishment provided by an international treaty is justifiable only if it has the nature of a "crime". But what is the criterion of a crime-not de lege lata but de lege ferenda-what justifies the "punishment" of an act? It is the fact that the act is harnful not only to the individual directly injured by it, but to the whole community. If the act constitutes a violation of international law, the punishment of the individual perpetrator is justified if the act is harinful to the international coinmunity. The Advisory Committee of Jurists appointed by the Council of the League of Nations in February, 1920, for the purpose of preparing plans for the establishment of the Permanent Court of International Justice, discussed the question of conferring upon the Court coinpetence in crininal matters. In the course of the discussion, Baron Descamps raised the question, "Do crimes against the Law of Nations exist?" He answered the question in the affirmative by defining these "crimes" as acts "of such a nature that the security of all States would be imperilled by them." 41 The formula "imperil all States" means about the same as the perhaps better formula "harmful to the international community." The Committee did not clear up the question as to which violations of international law "imperil all States". But it seems that Descamps took it for granted that not all violations of international law are "crimes", in the sense of his definition. He considered it necessary to authorize the International Court "to define the character of the offense", 2 which prob-

40 See Kexsen, op. cit. supra note 2, at 145; Kelsen, Compulsory Adjudication of International Disputes (1943) AM. J. INT. LAw 397.

41 Permanent Court of International Justice. Committee of Jurists. Proces-verbantex of the Proceedings of the Committee. June 16th-July 24th, 1920. The Hague, 1920, p. 498.

42 Ibid. 521. Baron Descamps took his idea from the institute of ministerial responsibility established by the constitution of his country. He said (p. 512): "The Belgian Constitution, which is so liberal, and so scrupulous in its enforcement of penalties, does not hesitate to lay down that the House of Representatives may bring charges against the Ministers and bring them to trial before the Court of Cassation, which is expressly 
ably means that the Court shall decide whether the offense has the character of a "crime" or not. It is, however, hardly possible to draw a clear line between violations of international law which are harmful to the international community and therefore crimes for which the individual perpetrator may be punished, and violations of international law which are not of such a nature. Since any violation of the law is harmful to the legal community, the legal order attaches to any violation a sanction. The only difference that exists concerns the degree to which a delict is harmful to the community. To acts considered more harmful the national legal order attaches punishments, to acts considered less harmful, civil execution. A differentiation of the sanction into punishment and civil execution can hardly be introduced into international law. But, as we shall see later, sanctions which are to be directed against individuals made responsible for violations of international law can be much more easily differentiated than they usually are in national criminal law. It is not possible to distinguish "punishment" by an absolute criterion from a sanction which has not this character. It is therefore advisable not to speak of "punishment" in connection with the problem of individual responsibility for violations of international law, but of individual sanctions, in contradistinction to collective sanctions of general international law, or, when using the term "punishment", to define it as a sanction directed against an individual made responsible for a violation of international law.

With respect to the individual responsibility to be established for violations of international law, we must distinguish violations of international law committed by acts of State and violations committed by acts which do not have this character. Among the former four groups of offenses can be distinguished: offenses (1) committed by resorting to war in disregard of general or particular international law (Kellogg-Briand Pact, and the like); (2) committed by provoking war-that is to say, by committing the international delict against which war is a just reaction( this delict is of no account when the Covenant establishing the Court permits war only as a collective sanction executed by the League); (3) by violating the rules of war-

invested with power to define the offence and to determine the punishment." Individual responsibility of the organ of State for a violation of international law is, indeed, analogous to the individual responsibility of a member of government for a violation of the constitution or another rule of national law (impeachment in Great Britain). 
- fare; (4) by violating other norms of general or particular international law. ${ }^{43}$

The trial of the guilty individual may take place in conjunction with the procedure of the court in an action by a State or by an international agency (such as the Council of the League) against a State accused of having committed one of the offenses mentioned sub 1-4. After having decided that a State has violated international law, the court may at the request of the injured State, open a procedure against the individual (or the individuals) who, as organ (or organs) of the guilty State is (or are) responsible for the latter's violation of the law. In case of offenses mentioned sub 1 and 2, the procedure against the responsible individual may be opened also at the request of the international agency, if such agency also be established by the Covenant.

The punishment inflicted by the court upon the individual declared as responsible for his State's violation of international law, does not prevent the court from imposing upon the guilty State the obligation to repair the wrong done. The penalties to be inflicted upon the guilty individuals should be determined by the court in accordance with the criminal law of the State of the accused. Since, however, the acts mentioned sub 1 and 2 do not constitute crimes according to national law, the court may be authorized to inflict upon the guilty individual in case of an offense mentioned sub 1 and 2, any penalty which the court thinks to be adequate. Death penalty, however, should be excluded if the criminal law of the accused does not provide this penalty: In case of an offense mentioned sub 3 (war crime), the court should inflict upon the accused the penalty which the criminal law of his State would provide for the act if it had not the character of an act of State but were an ordinary crime.

Just as the offenses mentioned sub 1 and 2, the offenses mentioned sub 4 do not, as a rule, constitute acts which, according to national - law, would be crimes if they were not acts of State. In most of the - cases concerned, the delict of the organ responsible for his State's violation of international law is much less harmful to the international community than in the cases mentioned sub 1 to 3 . Consequently, the individual sanctions to be attached to these delicts, if the latter do not constitute crimes according to general criminal law, must be

43 In the discussion of the Advisory Committee of Jurists, Lord Phillimore differentiated: 1 . Acts committed in time of peace; 2 . Crimes of war; 3. The crime of having made war. Ibid. 507. 
much less severe than those inflicted upon war criminals or the authors of a war. The purpose of the penalty in the cases concerned should be to stigmatize the guilty persons morally and politically rather than to inflict upon them a physical harm, such as imprisonment or fine. Such penalties are: the loss of all political rights, the loss of capacity to hold public offices, both for a certain period of time or forever. The court may even restrict its sentence to the declaration that the accused has violated international law (or is personally responsible for his State's violation of international law).

Violations of international law by internationally injurious acts of individuals which are not acts of State are divisible into two groups: (1) acts of individuals whom the State to which they are subject is obligated by international law to punish; to this group belong war crimes committed not at the command or with the authorization of the government (when the delinquent has fallen into the hands of the authorities of the injured State, there exists, as a rule, concurrent jurisdiction of the latter); (2) acts of individuals whom the State to which they are subject is not obliged to punish but whom either all the States or the injured States are authorized by international law to punish or submit to a sanction which has not exactly the character of punishment; to this group belong such acts as piracy, breach of blockade, carriage of contraband, espionage, war treason, and the like.

If an international court is established competent to decree sanctions not only against States for violations of international law, but also against individuals responsible for these violations, it is not necessary to confer upon this court, as to a tribunal of first instance, jurisdiction over individuals who have violated international law by acts which have not the character of acts of State. If their State-as in the case mentioned sub 1 -is obliged to punish them, and if it does not fulfill this obligation although the delinquent is within its legal power, the injured State is always in a position to bring the guilty State and its responsible organ to justice before the international court. It is, however, possible and advisable to give the injured State the right of appealing to the international court if the sentence of the national court seems not to be satisfactory. If the delinquent is within the legal power of a third State, inember of the League, the State obliged to punish him should be bound to ask for his extradition and the third State obliged to grant it. When the delinquent is sentenced not by a court of his own State but by the court of a foreigu State and, in particular, by a court of the injured State, the sentenced individual as 
well as his State should have a right of appeal to the international court. The substantive law to be applied by the international court must be the law of the court against whose sentence appeal has been made. In the cases mentioned sub 2, it is likewise advisable to confer upon the individual sentenced by a national court, and if the accused is a citizen of another member State, to his State, the right to appeal to the international court. If the national court has applied in its sentence national criminal law, as im the case of piracy, the international court as court of appeal, has to apply the same national law. If the national court has decreed a sanction directly determined by international law, as in the case of breach of blockade or carriage of contraband (confiscation of the vessel and the cargo), the international court has to apply international law.

Acts of individuals which are not acts of State are, as a rule, violations of international law, since they are internationally injurious -injurious to a State. It is, however, possible that an international treaty obligates the contracting States to provide punishment for certain crimes which do not constitute an injury to another State, but whose punishment is in the common interest of the contracting States, such as traffic in opium, and the like. In these 'cases too, the international court may have jurisdiction as a court of appeal, and the accused as well as each contracting State may have the right to appeal from the competent national court to the international court. The latter nay also decide conflicts of competence between national courts.

Any person directly injured by the delict which is the subject of the judicial procedure may, if authorized by the court, and subject to any conditions which it inay impose, constitute himself partie civile before the court; such person shall not take part in the oral proceeding except when the court is dealing with the damages. ${ }^{\text {th }}$

At the request of the international court any State as a member of the League should be obliged to commit to that court any individual who is under the jurisdiction and within the power of the State concerned. The court niay decide whether an individual who has been committed to it shall be placed under arrest, and under what conditions he may be set at liberty. The State on whose territory the court is sitting must place at the court's disposal all measures necessary

44 See Article 26 of the Convention for the Creation of an International Criminal Court signed on May 31, 1938, at the International Conference on the Repression of Terrorism, held at Geneva, November 1st to 16th, 1937. Proceednass of THE INTERNatToNaI CONFERENCE ON THE REPRESSION OF TERRORISM, op. cit. supra note 37, at 23. 
for effective judicial procedure, such as a suitable place of internment, a staff of wardens for the custody of persons placed under arrest, and the like. ${ }^{45}$

The orders and sentences of the international court should be executed by the State designated in the order or the sentence of the court. If a State fails to fulfill its obligation to execute an order or sentence of the international court, collective sanctions should come into operation provided by the Covenant constituting the League as a judicial community. 